\title{
The European Focus of the Curriculum in the Educational Reforms in Spain at the End of the Twentieth Century
}

\author{
Leoncio Vega Gil \\ Universidad de Salamanca, Spain
}

\begin{abstract}
This comparative research study seeks to explain and evaluate the European perspective of the school curriculum and its repercussions on school reforms implemented in Spain at the end of the twentieth century. First, a study is made of the interpretations, content and pedagogical characteristics of the European dimension of education. In the second part of the study the European aspects of the Spanish educational reform are analysed and evaluated, taking into account both the levels of the school system and how it affects teacher training. This analysis considers both the reforms carried out by the Socialist government (Organic Law on General Organisation of the Education System - LOGSE) and the actions of the conservative government currently in power.
\end{abstract}

Key Words: curriculum, comparative education, european dimension, school reform

\section{RESUMEN}

El presente trabajo de investigación comparada pretende explicar y valorar la perspectiva europea del currículo escolar y la repercusión de la misma sobre las reformas escolares operadas en la España de finales del siglo XX. En un primer momento se estudian las interpretaciones, contenidos y características pedagógicas de la dimensión europea de la educación. En el segundo bloque del trabajo se analizan y valoran las expresiones europeas de la reforma educativa espańola teniendo en cuenta tanto los niveles del sistema escolar cuanto la plasmación en la formación de profesores. Análisis que se efectúa de la reforma de carácter socialista (plasmada en la Ley Orgánica General del Sistema Educativo) y también de las acciones de gobierno del partido conservador actualmente en el poder.

Palabras clave: currículo, educación comparada, dimensión europea, reforma escolar

\section{RÉSUMÉ}

Cette étude comparative de recherche vise à expliquer et à évaluer la perspective européenne du programme d'études scolaire et ses répercussions sur les réformes éducatives réalisées en Espagne à la fin du vingtième siècle. Au début, on examine les interprétations, le contenu et les caractéristiques de la dimension européenne de l'éducation. Dans la deuxième partie de l'étude, on analyse et évalue les aspects européens de la réforme éducative en Espagne, tenant en compte autant les niveaux du système scolaire que la manière dont le système scolaire affecte la formation des professeurs. Cette analyse considère autant les réformes réalisées par le gouvernement 
socialiste (La Loi constitutionnelle générale du système éducatif-LOGSE) et les actions du gouvernement conservateur actuellement au pouvoir.

Mots-cléfs

programme d'études, education comparative, dimension européenne, réforme éducative

\section{Introduction}

$\mathrm{I}$ $\mathrm{N}$ THE PRESENT STUDY we seek to approach the so-called European dimension of education with special attention to curricular content; this means directing attention to a point or problem that we try to solve using some prior assumptions. This is the direction that we think education should take in the process of European construction, given that it implies orienting education from the different school systems and projects (formal and non-formal) toward the European outlook.

Moreover, our references will focus in greater detail on the question of content, but also heeding other pedagogical action such as extracurricular activities, language learning or the official approval of degrees. Thus, we start from a broad interpretation of the term "curriculum," which is almost a synonym of school in that it encompasses all educational activity carried out in schools. This will be dealt with in a twofold manner. On the one hand, a reading will be made of the actions of the Spanish school system, and on the other hand, we shall try to take into account, in greater detail, the contributions that these actions have made on a more general level in Europe, especially the projects and studies coming from the Council of Europe.

\section{Concept \& Content of the European Focus of Education}

We are aligned with J. Delors' Europeanism when he defends the idea that the European cultural dimension implies or entails posing the subject of European identity, and this inevitably leads us to European identities. In any case, this identity (or identities) invites us to agree on some general characteristics of this community based on law and co-existence, which is Europe. A first characteristic would be precisely the plurality or diversity of religions, languages, art, gastronomy, climate, agriculture, thought, landscape, etc. A second is defined by our having had a common history which started with the democratic political structure inspired by the Greeks; the legal organisation inspired by the Romans; the construction of Europe in the sixteenth, seventeenth and eighteenth centuries; the cultural and reformist movement of the Enlightenment; the nineteenth century philosophical movements; school reform centred around the "New School" movement, etc. A third characteristic is that we have what Delors calls the "soul of Europe," the doubt and examination of conscience that invite us to think of the Cartesian methodical doubt and that Handrik Brugmans (who would become Head of the European College in Bruges) would rightly specify when he wrote that "no certainty is accepted as truth but rather is constantly rediscovered." This is a thesis close to or complementary to the one defended by Edgar Morin (1988) when he defended the idea that the European spirit and foundation is centred on the intellectual tension constructed in the historical process from classical antiquity to the present, and which is expressed in the antinomies of modernity-tradition, empiricism-rationalism, new 
school-traditional school, humanism-scientism, Catholicism-laicism, faith-science, etc. That is, the cultural synthesis of what is European is the product of the equilibrium and consensus brought about by ideological, mental, social and cultural conflict (confrontation).

Taking into account the political, institutional and programmatic development of the Union, we can agree that the educational construction of Europe began in the I970s (we are aware that the contributions from the Council of Europe began in the I950s and that they were of major importance for the beginning of this stage; however, the geographical perspective exceeds the boundaries of the Union) with the setting in motion of several meetings of Ministers of Education that concluded with the passing of the Resolution of 1974 and the First Program of Community Action in education (Resolution of the Council and of the Ministers of Education, 1976). As regards the European perspective of education, also of interest, besides the program referred to, is the impetus given in 1985 through the conclusions passed by the Ministers of Education, the Green Paper published in 1993 and the Socrates Program started in 1995. Below we shall make some observations on these three events in the Union's educational policy.

The Action Program in education passed by Resolution of the Council and the Ministers of Education in 1976 has, in fact, become the first cooperative program for European action in education. It was the first serious step towards the construction of Europe through education. Section 5 includes some proposals for strengthening the European dimension of education, in this case, for teachers and pupils at primary and secondary schools in the Community. These suggestions range from study visits for teachers to the cooperative development of activities and experiences, passing through exchanges (information, experiences, activities), mobility (teachers and pupils) and contact between the management teams of different schools (Etxeberría, 2000, p. 24).

The Green Paper or working document dated 1993 was intended to bring together future European policies in Community education (Commission of the European Communities, 1993). Thus it proposed the creation of a stable legal framework to regulate actions of cooperation in education, reflect on the means and ends of the European focus of education, delimit the curricular axes of complementary and subsidiary community action and prepare young people to take on their responsibilities in the context of a single market. These bases are further articulated through the three coordinates that the document determines. The first would be the legislative framework of action of the member states that would act on questions such as the quality of education, collaboration between countries, respect for cultural and linguistic diversity and the development of specific actions (language teaching, student mobility, cooperation between centres, exchange of information, distance education, etc). A second coordinate would be delimited by the objectives sought through the European dimension of education, which centre on the contributions of the school to European construction (developing practices orientated towards the equality of opportunities, responsibility, autonomy, critical judgement, innovation, personal enrichment, keenness and motivation for learning, etc.; that is, European civic and moral values) and the construction of the European citizen. A third element of action would focus on the school in its 
administrative and teaching aspects; the role of the school as a European agent is of major importance since it brings diverse groups into contact (pupils, parents, teachers, authorities, associations and other social groups).

For us the most significant institutional expression in European construction of education can be seen in the Socrates macro-program whose coordinates are the fomenting of the European dimension of education and the teaching of European languages; the latter is also implicit in the former. The European Union approved this cooperation program on 14 March 1995 for a temporary period which concluded at the end of 1999 (Council Decision 95/819/EC). However, the Council of Ministers has approved its renewal; this second edition formally came into force on I January 2000 and will end in 2006 (Decision 253/2000/EC). In this re-edition the intention is to make a considerable effort as regards budget in order to reach all the social strata of Europe.

Two of the great novelties in this program, with respect to the previous ones, would be the attempt to increase the levels of academic and intellectual quality of the beneficiaries on the one hand and, on the other, the simplification and unification of the administrative procedure for organising and managing the different activities in the program, given that management is centralised at each university through the presentation of the proposal of institutional contracts between each university and the European Commission.

The Socrates Program (in which Is member states of the Union take part, besides other eligible ones from central and eastern Europe-Hungary, Poland, Romania, etc., and from the north-Iceland and Norway) is the program specifically designed to promote the aquiring of European languages and the development of the European dimension of education at all levels of the school systems through actions oriented towards strengthening cooperation between schools, student and teacher mobility, the exchange of information and experiences, adult education and the recognition of degrees and other actions. The global actions of the Socrates program include higher education (Erasmus), school teaching (Comenius), the promotion of language learning (Lingua), open and distance teaching, questions of common interest relating to educational policy, the European network of information on education (Eurydice), study visits for those responsible for education (Arion), the network of national information centres concerning academic recognition (Naric), adult education and complementary measures. It also allows for connections and common development with other programs, such as Leonardo da Vinci (vocational training) or youth programs.

However, of all the actions developed by the Socrates Program in matters concerning the construction of European education, we shall make a greater effort to explain three major actions in the socio-educational perspective; with this we aim to see the European dimension of education in its social aspect, that is, to make European education reach all social groups, and not just those already integrated. This would include the education of the children of migrant workers, open and distance education and adult education. As regards the first, within school education Action 2 is devoted to the education of migrant workers, of those who have itinerant occupations, of travellers and gypsies (intercultural education). The overall aims include having the groups 
of children mentioned above participate as fully as possible in all school activities, supporting their integration, giving them equal opportunities and better quality of education, responding to their needs and promoting specific learning. The pupils should also become involved in a social integration characterised increasingly by cultural and linguistic diversity at the same time the effort is made to combat racism and xenophobia. Activities in this action are divided into four sections. First, education of the children of migrant workers; this collective encompasses between $7 \%$ and $9 \%$ of the school population of the Union's member states. Special attention is given to the teaching of the language of the host country and of the languages and cultures of the country of origin. Secondly, the education of the children of travellers and gypsies; about 2 million of this group are currently living in Community countries and, of these, about half are of school age. This group is ever more aware of the need to overcome the social problems inherent in illiteracy; the European institutions in turn guarantee respect for their way of life and their own culture. Activities are oriented towards primary and secondary education, the transition between school and work, the forming of Gypsy mediators and the use of open and distance education (Comision Europea, I997). Thirdly, this action comprises the education of the children of itinerant workers, such as sailors, fairground workers, and circus families. The projects are concentrated in networks of pre-school centres and in the training of teachers for these centres, in the use of open and distance education, in the transition between school and active life, in networks designed to improve the quality of education in information and in guidance for parents and in trans-frontier cooperation. Finally, the action includes a section designed to promote intercultural education. The aim of these projects is to help school children to discover the factors that unite and differentiate humanity and acquire a critical and comprehensive knowledge of cultures (including their own). These projects are addressed to all schools, but especially to those where there are pupils and teachers from different linguistic and socio-cultural groups. Their reference point is the comparative study of different cultures with a view to motivating the students to develop attitudes of intercultural communication and increase respect and understanding among them, regardless of cultural, linguistic or ethnic origin.

However, despite institutional, administrative, curricular, social and political effort, the difficulties in integrating these groups into European societies is still a challenge for the democratic principles that are the foundation of the Union's institutional action. To a large extent, this is a situation that attempts to resolve itself without very much conviction and which is being tackled only partially, given that these groups have a culture, a life, and material limitations that do not allow educational action to achieve the foreseen objectives of cohesion and integration because they do not form part of a global and structural project. Nevertheless, they serve to morally and politically relax the principles that form the foundation of the Union that the European (urban) middle classes seek to build.

As regards European projects designed to promote open and distance education, it must be said that since the eighties, European international organisations have marked a clear policy of support for this school dimension, which should have a special impact on youths and adults. In 1989 the Parliamentary Assembly of the Council of 
Europe passed a recommendation advising intergovernmental cooperation in the field of distance education (Recommendation IIIO, I989); the same year the Council of Ministers of Education invited the member countries to invest in and take advantage of the new technologies of information and communication as suitable mechanisms for the practice of open and distance education (Resolution on the information society, 1989). In the European Community, various documents at the beginning of the nineties emphasized the advantages of distance education for continuing education, the integration of different programs and their methodological particularity. As a result, the Council of Ministers of Education held in Brussels on 27 November 1992 agreed to clarify the criteria and the political lines of the Community's action regarding non-formal and distance education (Conclusions of the Council and the Ministers of Education, 1992). The idea was to facilitate cooperation between the different institutions and bodies working in the sector, foster the training of teachers, highlight the importance of tutored evaluation and gather information for the states, agents and associations working on the matter. These policies would become manifest in projects sponsored by the Socrates Program, which seeks to promote the exchange of experiences, the evaluation and diffusion of innovative methods through new multi-media educational approaches, the designing of new pedagogical material, including didactic computer programs and the development and diffusion of viable methods for improving educational capacities through distance and open teaching and for training teachers in their use.

Nevertheless, cultural diversity, the number of languages used and the differences in educational traditions continue to hinder the setting in motion of authentically European projects for distance education, given that most of them are applied individually in each member country of the Union. Some European trends in distance education can be perceived: adaptation to the needs of human resources, both on a national and sub-regional level; the challenge of involving conventional institutions in practice; the involvement both of traditional institutions and those dedicated to distance education in the efficient use of the new information and communication technologies for education and training; the need for an adequate balance between national and European development as regards policies, infrastructure, quality, official recognition of qualifications, projects, back-up systems, etc.; and the need to use these programs of distance education to support groups living in areas with greater difficulties for development.

As regards adult education, the Socrates Program promotes the European dimension of adult education interpreted from an educational rather than an economic and professional point of view; that is, linked to educational, cultural and social frameworks and to the concept of European citizenship from the interpretation of education as life-long learning. Two types of measures are supported in this context: those intended to increase the sensitivity of organisations devoted to adult education to the importance of European subjects (the diffusion of knowledge about the cultures and traditions of the participating countries and the improvement in language competence in these countries, as well as improving the knowledge of adult students regarding political, economic and administrative matters of the European Union), and pilot 
projects for promoting the development of the organisations dedicated to adult education as regards topics of interest (guides and databases, seminars for the exchange of experiences and practice, evaluation and recognition of competence of adult students and the development of modules for training teachers of adults).

The European focus of teaching and learning, from the school perspective, presents some general coordinates for orienting characteristics of institutional practice. First, it is not so much a matter of specific subjects present in the study plans of primary and secondary education or teacher training, but rather the idea is to provide a focus in European perspective on the subjects already existing and being taught, such as literature, economics, history, sociology, geography, etc. This focus requires not only that the schools treat the European perspective within a certain discipline, but also, and above all, that they treat it in an interdisciplinary way; furthermore, the European syllabus should have continuous development in school systems from primary education to University. In short, in this characteristic we wish to underline the importance of re-orienting the curriculum to European referents, which implies making Europe the backbone of school action in the classrooms and educational areas. This is the case, for example, of history, which should focus the program content on Europe, and from this starting point incorporate national, regional and local analysis.

Second, a greater organisational effort must be made to include the study of European languages in the curricula so that each student will have the opportunity of handling two European languages besides their mother tongue, with a view to favouring integration and communication within the Union. Comparative European studies continue to point out the deficient command of European languages both in the social and school framework (Commission Européenne, 1995) despite the great budgetary and programmatic effort being made from European institutions. The key to full European integration and to the construction of the European citizen is communication, understanding and comprehension.

Third, the European focus of the curriculum should go beyond the study of contents and approach a series of complementary activities whose centre of action stems from the European perspective. This is the case for school weeks, field trips, visits to institutions, talks, courses, etc., which make it possible to know about, reflect on and become aware of European social problems such as immigration and its consequences, xenophobia, the environment, the integration of the differently able, etc.

Fourth, we must continue to favour and foster the exchange of information and experiences as well as teacher and student mobility as it is being carried out through the Comenius action of the Socrates Program. In this sense it is necessary to point out the existence of some limits to going deeper into the European perspective of education and teaching (Aguilar Hernández, 1999). On the one hand, comparative studies on European school systems tell us that the European systems of the member states have their own structural and organisational characteristics, both in academic organisation by levels, stages and cycles and in the shaping of study plans, so that the academic mobility of students is hampered by repercussions for the recognition of studies. These divergences contradict the European focus, which requires some minimum standards of uniformity. On the other hand, and in close connection with 
the first, we must emphasize the fact that the Union only acts in support of and as a complement to systems, given the principles of subsidiarity, since responsibility for the organisation and functioning of the school systems falls to each member state of the Union. Nevertheless, despite the educational paradoxes and academic divergences in European construction, more and more students are studying for a period in a country other than their own and there has been a progressive increase in exchanges and language learning.

Fifth, the European dimension or focus of education also requires responsibility or responsibilities as Dominique Barthélémy emphasizes (Consejo de Europa, I999a, p. 30), and it is generally agreed that this focus should be on quality in teaching, which can be measured by results. This is the functional perspective of knowledge and learning applied to European construction. Thus the idea is that the European perspective of education should be capable of fostering democratic values in co-existence, comprising a multi-cultural society, serving as an instrument for information and communication among citizens and establishing the need for life-long education. In short, this focus of the curriculum should be capable of favouring an active, critical, participatory and responsible attitude in individuals. Therefore, this measurement of results is posed in social, cultural and political terms and not in an economic or professional perspective, which would lead us to the interpretation of education as a market commodity.

\section{European Expressions of the Curriculum in Educational Reform}

\section{The State Perspective}

As regards the perspective of the involvement of the governments of the member states of the Union, efforts are being made through intervention on several fronts of action. When considering the case of the Spanish government, first we must point out a block of measures such as curricular changes in the different stages of the school system, the organisation of colloquia, seminars or work groups, the diffusion of educational material and projects for educational innovation, bilateral and multilateral exchanges of students and teachers and sensitising campaigns concerning community matters. A second front of action is the legislative framework which is expressed in several Ministerial Orders (October 30, 1992, on school exchanges and February 28, I994, on the procedure for filling vacancies for state teachers abroad) and a whole battery of Decrees (IO27/1993 of June 25, on the regulation of educational action abroad; 806/1993 of May 28, on the system for foreign centres in Spain; 1396/1995 of August 4, on the recognition of vocational training of member states of the European Union; 2073/I995 of December 22, on the recognition of degrees and I754/1998 of July 3I, which regulates the incorporation of Community directives to Spanish law). ${ }^{1}$

A third government action is defined by the setting in motion of bilateral cooperation programs such as Conversation Assistants (Spanish and foreign), Post to Post, exchange of university professors, scientists, researchers and experts, Controlled Experiment for the Early Teaching of Living Languages, Award Students, SpainUnited Kingdom Agreement. 
Fourth, mention must be made of involvement in the development of multilateral cooperation programs such as Socrates, Leonardo da Vinci and Youth with Europe.

Fifth, we have all the activity of cooperation with the Council of Europe. The conference of Ministers of Education held in Kristiansand (Norway) in 1997 approved three programs which gave continuity to others that were ending, namely: the teaching of the history of Europe in the 2Ist century, linguistic policies for a multilingual and multicultural Europe addressed to favouring greater diversification in language education and education for democratic citizenship. The latter offers three general lines of action: the conceptual framework of democratic citizenship, the identification of innovating experiences in schools and the preparation of didactic material. Another program that has been in effect for several years is the one called Europe in the School, which is expressed in the organisation of competitions for public and private schools by having students present projects on a predetermined subject (Peace in Europe, tolerance, etc.). Later, we shall return to the outstanding role that the Council of Europe has been playing in the educational construction of Europe beyond the Union since the fifties.

\section{The Compulsory School System According to the Law on General Organisation of the Education System (LOGSE)}

\section{Primary education.}

The first referent for the Spanish case can be found in the 199I Decrees (I006/I99I of June I4 \& I344/I99I of September 6), which established the minimum instruction corresponding to primary education; the second referent established the curriculum (objectives, content, evaluation criteria and didactic methodologies) for the whole geographic and administrative territory dependent at that time on the central education administration of the State. Also to be taken into account is the fact that the common curriculum comprises $65 \%$ of the total curriculum for the Autonomous Regions whose only official language is Spanish and 55\% for those regions that also have their own language (the Basque Country, Catalonia and Galicia). The aforementioned decrees specify the curricular areas of primary education as the following: knowledge of the natural, social and cultural milieu; art education (usually art and music); physical education; Spanish language and literature (oral and written communication, and reading and vocabulary); foreign languages; and mathematics. Thus, in the only area of teaching where we find curricular elements of European dimensions is in the one referring to knowledge of the milieu; in the content on social organisation, point number five includes the concept of European Community with two subheadings which orientate its practice at school: one on "countries forming it" and the other on "common traits and interests." As regards procedures for establishing this concept we have the teaching strategy of gathering and interpreting information on events in the European Community through the mass media. The use of the institutional name of the EU as it was called prior to Maastricht should be noted, but what is more important is the introduction of European curricular elements common to every primary education study plan. 
However, reference must also be made to the complementary curriculum known as "transverse axes" or "cross-curriculum"; these are contents and practices present throughout infant education as well as primary education and compulsory secondary education, but they are not of a fundamental, stable and basic nature, although with respect to the curriculum they are developed from the areas of general knowledge that explain the general content. These units deal with moral and civic education, education for peace, education for health, education for sexual equality, environmental education, sex education, consumer education, and road safety education. The study of the cross-curriculum (objectives, content and activities) reveals that the European perspective does not appear explicitly in any of the cross-blocks.

\section{Secondary education.}

The Decree 1345/199I of September 6, which established the curriculum for compulsory secondary education, set up nine academic areas of curricular organisation of studies for the first stage of secondary education (I2-I6 year olds). These areas were specified as natural science, social science, geography and history, physical education, art and visual education, Spanish language and literature, foreign languages, mathematics, music and finally, technology.

In this case we also find interesting the presence of the European dimension of teaching throughout the whole curricular flow chart (objectives, content, specifications, and evaluation criteria in each of the general areas forming the curricular design).

In social science, geography and history there are some references, such as the fact that the pupil needs to know, understand and evaluate the immediate environment and the human and social community in its different spheres (one of them being the European sphere). However, in the general objectives of the area there is no direct reference to the social and cultural characteristics of European societies. As regards content, references to "Europe" or "European" appear only five times: one in relation to demographic structure; another on agricultural areas; the third and fourth refer to historical regimes (feudal and ancien régime); and the last refers to the presence of Spain in the world, and in this case, it comes with Community. In the evaluation criteria, references to the evaluation of the content mentioned previously again appear.

If the presence of Europe in the area of social sciences is only circumstantial and tangential, in the area of foreign languages we find that the topic "Spain" appears twice whereas "European Community" appears only once. In the other areas there is no express connection with the European focus.

Consequently, we do not think it is possible to affirm the existence of a European perspective in the curricular organisation of compulsory secondary teaching in the Spanish educational reform of the r99os. 


\section{The Curricular Reform of the Conservative Government and the European Perspective (Compulsory Secondary Education and Higher Secondary Education)}

Mention must also be made of the reform process begun at the end of 2000 by the Ministry of Education, which expresses the determination of the governing conservative party to undermine the political and pedagogical bases of the prior socialist reform. Moreover, we must also take into account the fact that the transfer of educational administration to the Autonomous Regions has now been completed and that the regions therefore have normative and executive power over the school system in their respective areas. Thus, there seem to be three governmental actions that mark this new stage of political and curricular reorientation of the school system: two decrees and a project of law. The decrees, (3473/2000 and 3474/2000, of December 29) deal with the reform of the minimum content of compulsory secondary education $(E S O)$ and higher secondary education (Bachillerato, for students 16 to I8 years old); that is, the much discussed reform of the Humanities. The history syllabus, for example, is being reformed, giving more academic weight to the history of Spain. One of the reasons that justifies a greater homogeneity of the syllabi lies precisely in the European perspective; it would be a matter of favouring the mobility and integration of families that move from one community to another. The intention is to increase the hours devoted to language, mathematics, philosophy and the study of classical culture. In exchange, music, art, physical education and education in values will undergo a reduction in hours unless the Autonomous Regions make changes. This is already occurring in some regions (Andalusia, Aragon, Asturias, the Canary Islands, Cantabria, Castilla-La Mancha and Extremadura), which have had to increase by one or two hours the school schedule in Compulsory Secondary Education (going from 28 to 30 or from 30 to 32 hours per week) so as not to reduce the time devoted to music and art, given that the decrees come into force during the academic year 200I-2002.

As regards the project of Law on Quality of Teaching, this seeks to solve the problem of failure at school "generated" by the Law on General Organisation of the Education System (Ley Orgánica I/Ig9o de Ordenación General del Sistema Educitavo), which raised the school leaving age from I4 to I6, meaning that young people who previously would have abandoned the system were now obliged to remain in it (the socialist reformers argued that this extension was due to cultural, psycho-pedagogical, labour, and social reasons and European integration) and which has led to about $25 \%$ of students having difficulties in achieving the proposed academic objectives. Versus this single itinerary (product of the concept of the comprehensive school), the conservative party is now proposing three new itineraries: one for those who are not going to continue their studies, another for those who are going on to vocational training and a third for those who intend to go on to higher secondary education and are in a position to do so. Hence, in the second stage of ESO there is a route for those who are lagging behind, another for vocational training and another for the academic stream. In some aspects it reminds us of the proposals and institutional development of the I970 General Law on Education (Ley I4/I970 General de Educación y Financiamiento de la Reforma Educativa). 
At bottom, and on the surface, it is a matter of dismantling the structure of the educational system established in the 1990 Law on General Organisation of the Education System, which has a social-democratic nature and foundation, especially as regards the profile of compulsory secondary education, which responds to the European model of comprehensive school, a progressive model of school which should have been developed in Spain in the I960s as it was in other European countries, but, given the totalitarian context of the Franco regime, its application was not possible and it was necessary to wait until the I990s when European societies were already demanding more diversified, productive, social and cultural school systems. The reasons for this conservative re-orientation of the system, in our view, are basically four: (I) a political one, in the sense of trying to contain the administrative decentralisation (in this case, in education); (2) an ideological one, consisting of interpreting education as an instrument of differentiation and not of equality in the purest liberal style; (3) of a professional nature, given that some sectors of secondary school teachers accuse the reform of being flexible (automatic promotion), not academically demanding enough and of being imbued with a pedagogical and psychological spirit (the theoretical-practical model of constructivism); (4) a curricular and cultural reason in the sense that the Spanish Socialist Worker's Party reform insisted on music, arts and crafts and education in values as curricular novelties, i.e., a type of education addressed to socialisation and the adaptation of the citizen to his/her surroundings. This is where the reform of humanities comes on to the scene, and, with the allegation of deficiencies in humanistic instruction, a curricular extension in mathematics, philosophy, history and classical cultures is posed with the consequent reduction of the hours devoted to the content and activities of the most emblematic programs of the I990 Law's curricular identity which we referred to above.

As regards minimum teaching for the whole country, the curricular structure established by the Law on General Organisation of the Education System for compulsory secondary education was modified by Royal Decree 3473/2000 of December 29. A first look at this document allows us to confirm that neither the introduction nor the general objectives of the reform include any reference whatsoever to Europe or the European Union. Given that the list of academic areas is maintained, we shall analyse whether the European dimension appears in the curricular development, as we did with regard to the I99I decree. As occurred in the 199I document, the curricular area where most references to Europe occur is in the area of social sciences, geography and history. In the introduction, the European geographical perspective is mentioned twice. However, in the thirteen educational objectives to be developed in the area of knowledge, neither "Europe" nor "European" appear anywhere, either as an objective or as an internal reference. Nevertheless, in the content for the first year a European reference appears that refers to "the temperate environments of Europe and Spain"; in the second year there are three references to the "map of the European Union," "feudal Europe" and "Europe from the IIth to Isth century." Also, in the evaluation criteria for these two years there appears the need to identify physical features, the political map and historical periods with special reference to Europe and Spain. The third year includes the study of content on "large regional groupings and groupings of some 
States, with special attention to Europe and Latin America"; the evaluation criteria for this year include the description of environmental effects in Europe and Spain, the geographical characteristics of the European Union and the effects of the integration of Spain in the Union. The program of content for the fourth year of compulsory secondary education incorporates seven European references: four in the historical perspective and three on the world today (construction of European unity, current situation of Eastern Europe and the democratic governments and integration in Europe). Thus, if we compare the Europeanism expressed in the area of social science both in I99I and in 2000, we can confirm that in the latter year, although the program does not have a European focus, it has advanced considerably, both in the introduction of content and practices of European reference, such as the Spain-Europe comparison. However, it must be said that several of the European references are not the product of a curricular design with a European focus, but rather the logical expression of the internal content of the area in its inevitable contextual reference in human sciences as is the case of geography, history or the study of social structures.

Another area of knowledge that we analysed before for references to Europe was that of foreign languages; whereas in I99I in the introduction only one reference to the European Community appeared, in 2000 there were three (one on the European Union and two on the Council of Europe). On checking the programs for the area, a clear and determined educational bid for the study of foreign languages in Spanish compulsory secondary education can also be perceived.

With respect to the new curricular flow chart established for higher secondary education (Decree 3474/2000 of December 29) a first assessment must be made inasmuch as it implies an impetus for humanities according to the report of the working group formed in 1998 (Cano, 2000); this characteristic is expressed in the extension of the teaching of Philosophy (subject common to both years), Technical Drawing II and Technology (for three of the four modalities) and History of Music and Greek II for Humanities and Social Science. We understand this curricular reorientation in a twofold dimension; on the one hand, the "humanist" orientation of the curriculum is of a classical and traditional style (owing to the academic weight given to the history of philosophy, the history of music and classical languages) and not modern and European (humankind, their education and culture from Europe in a broad and cultural interpretation of humanities) (Morin, 200o). On the other hand, we think that, despite the four modalities and the introduction of new technological subject matter, we are facing a return to the classic, academic, traditional (science or arts) bachillerato and not a social and European one.

In any case, our aim is still to analyse the European focus in the curriculum. In this sense we find that the only subjects that include curricular action in a European perspective are foreign languages and geography. Some others, such as art history or contemporary world history include a few references such as "European context" or "Construction of Europe. The European Union." Thus, we are going to give a greater explanation of the curricular action of the subjects pointed out above. First we have foreign languages (a subject common to all the specialities), given that both the introductory explanation and the objectives include references where the importance of 
languages as instruments of communication and culture in European societies and also as instruments for constructing European identity is stated and these claims are based on documents from the Council of Europe. On the other hand, we must take into account the clear inclination towards European languages since the programs include German, French, English, Italian and Portuguese, which are the European languages most spoken in Europe (excepting Spanish).

The second subject of interest is geography (pertaining to the modality of humanities and social science) where "understanding the interdependence of all the territories that form Spain, and the European Union and other geographic areas in the world" is included as an academic objective. In the content of this subject, reference is made to Spain in Europe (in order to explain the process of integration and its consequences, as well as the characteristics of the territory).

Thus, the new Bachillerato is not oriented towards a European perspective either, but rather towards a Spanish perspective; this focus, above all, takes into account what the teachers have been explaining in their classes.

If we compare these European references with those established in Decree II78/1992 of October 2, we perceive a great leap towards the introduction of contents referring to Europe, given that in 1992 references to Europe were included only in the subjects of geography (study of area) and contemporary world history. In the first case, reference is made to Spain belonging to the area of the European Community and to European construction in north-south relations. In the second case, a reference appears describing the European Community in an evaluation criterion devoted wholly to the confirming of what has been learnt about the previous content.

\section{Teacher Training}

The reform of the curriculum for teacher training in Spain at the end of the century began in 1987 and came into effect in institutional practice a few years later. It was a reform required by the new organisation of the Spanish universities marked by the 1983 Law on University Reform (Ley Orgánica II/I983 de Reforma Universitaria). The 1987 general directives would set the new study plans that would be applied in the r99os. These directives entailed the establishment of a common curriculum for all teacher training centres (Faculties of Education, Teachers' Centres, University Schools of Education and University Teacher Training Schools), situated at around 67\% the total subjects to be taken by the student in order to obtain the Degree of School Teacher in the seven internal specialities (infant education, primary education, special education, foreign language [French or English], physical education, music education and hearing and language). In 2000 a revision of the study plans for teacher training was carried out. This last reform did not change the general lines of academic orientation of the study plans, given that it was merely a technical adjustment as regards the hours devoted to subjects or the fusion and change of some names of subjects. Hence, the common curriculum is still the one set by the 1987 decree. In relation to this curricular block we must state that there is no subject with a European denomination; neither did we find any European reference in the subject descriptors that specify the orientation of the content of the subjects. Nevertheless, some contents are explained in the 
individual programs of each subject with indirect reference to European geography, as is the case of the content on contemporary educational institutions and movements or the curricular dedication to the didactic aspects of the study of languages (French, English and German).

In the block of contents established by the respective universities (known as compulsory subjects) it must be said that, as regards the University of Salamanca (as an example of general orientation on a national level), there is no subject name or descriptor with European reference.

In the curricular block from which students choose their subjects we find some academic issues related to Europe in the study plans for teacher training taught at the centres pertaining to the University of Salamanca. Here we find optional subjects such as European Union, Rights and Values of European History, Comparative Education, and Comparative Pedagogy. Let us go into the curricular orientation of these subjects. In the case of the one referring to the European Union, we find that it is defined by descriptors such as "genesis of its formation from the Treaty of Rome to the Single European Act," "physical, human, economic and political elements" and "environmental problems." Thus it is an eclectic subject that groups together several European thematic questions from the perspective of social science. The subject on rights and values is of a historical nature (cultural, philosophical, and intellectual aspects) and is also general inasmuch as it does not geographically circumscribe the Union. The subject Comparative Education includes a descriptor on the comparison of the school systems in the European Union. And finally, the subject called Comparative Pedagogy shows an orientation that is methodological and also compares the problems of the school systems but is not circumscribed to European references.

In short, after studying the syllabi for teacher training in Spain and the specific ones for the centres belonging to the University of Salamanca, we can conclude that they do not offer training with a European focus. This means that the curricula for teacher training are not favouring the European dimension of education. On the other hand, the existence of some elective subjects with European academic references (besides the study of the languages of the speciality of foreign languages or the study of languages as curricular subjects) and also the fact that some course descriptions explain topics related to European actions, motivated by the authors or theories explained in the classrooms, must be mentioned. It is necessary not only to promote the European aspect in academic subjects and the study of languages, but also to give greater curricular weight to the comparative social-historical study of the school systems of the member states of the Union.

\section{The European Dimension of Secondary Education According to the Contributions from the Council of Europe}

The Council of Europe as a European international body has been functioning since 1949, and forty countries in Europe belong to it, among which are the fifteen in the Union. Since its creation, the Council has become the institutional driving force and impetus towards the institutional, political and administrative organisation of the Union. In educational and cultural matters the competent internal body is the 
Council of Cultural Cooperation, which is organised in several working committees. At the beginning of the I990s the Council started a research project under the heading "Secondary Education for Europe," addressed to young people in order to give them knowledge, competence and attitudes, to prepare them for access to higher education and an active life in a multi-cultural Europe, and also to make them aware of their rich European heritage. The results of this research program were included in two reports published in Spanish in 1999 (Consejo de Europa, 1999a, I999b), from which we shall extract some analyses and observations given the wide range of teaching professionals from different European countries that took part in the research processes and in the debates on the preparation of the final synthesis. These reports not only reflect the true school situation of the European focus in education, but also provide material, curricular and didactic resources, suggestions and topics that favour the preparation of school-work programs with a view to strengthening the European orientation of school action in the educational systems. Thus these documents largely respond to a challenge and a demand from classrooms and teachers who lack the guidelines, orientation, or resources necessary for developing a European focus in education, a focus which is gaining importance in the member states of the Union.

One of the major contributions of these documents is expressed in what are called pedagogical materials, which consist of a set of dossiers that can be applied in secondary education for developing the European perspective of education. They comprise a block of topics and supporting materials which would be agreed on, thus giving a manifold and diverse view of the European dimension. Their multi-disciplinary nature must also be pointed out. The topics tackled in these dossiers, which we can interpret as the curricular expression of the European focus of secondary education, are the following: (a) the industrial revolutions - the birth of a European technological area; Europeans and emigration; environmental damage in Europe - air pollution; (b) the rights of man; (c) discovery or encounter - Europe and the development of its empires; (d) guidelines for the presentation of the French Revolution from a European perspective; (e) macroeconomic database of the member states of the European Council; (f) Greek theatre and its influence on European literature and ideas; (g) the prevention of xenophobia, racism and anti-Semitism in order to build a democratic Europe; (h) identity, solidarity and a new geography of Europe; (i) and, finally, the Route to Compostela - a pan-European route (Consejo de Europa, I999a, p. 57).

We feel that this curricular program is diversified as regards content and clearly European in focus, and should be applicable not only to secondary education but also, with some adaptations, to primary education, and could even serve as a basis in the development of the European perspective in teacher training (primary and secondary). In schools this program could be developed in the form of specific curricular subjects or inter-disciplinary courses. However, the pedagogical formula that seems most appropriate would be its application as cross-topics incorporated in regular subjects of the various study plans. In addition, the topics are devised and organised so as to combine the constructive focus of knowledge (active pedagogy) and the teacher's informative and documentary contribution. For this purpose the dossiers are accompanied by a varied range of didactic resources (texts, graphs, maps, historical documents, etc.). 
Moreover, under the auspices of the Council of Europe, over the last decade a large number of practical activities have been carried out in the schools as innovating projects in the European perspective (Ozone, Baltic Sea, etc.), networks of links and exchange, short courses, classes, conferences, programs on minorities, competitions, awards, seminars, clubs, workshops and other actions. These initiatives reveal the interest in European topics of schools and professional groups related to education, and also the need for greater material, didactic and cultural support for the continuation of these projects, and the setting in motion of many other new projects.

As regards the Council's proposals for initial and continuing teacher training, rather than recommending an increase in the number of courses or subject matter the Council recommends giving greater European emphasis to those that already exist. In the documents referred to before, three general coordinates are stressed, which should be the basis for the initial training of teachers, namely: attitudes, general competence and specialized competence. With respect to the first category, there is a need for teachers to be involved in promoting pluralism and multi-culturalism; it is a matter of commitment to democracy and cultural diversity. Another aspect related to attitude refers to external cooperation (with local authorities, families, firms, trade unions, associations, etc.) and internal cooperation (with the management team, other colleagues, etc.). As regards the second category, general competence, emphasis must be given to: the importance of exchanges, the command of at least one foreign language (ideally two, as established in the Union guidelines), the knowledge of other educational systems (which requires a greater weight of comparative education in study plans), a general command of the new information and communication technologies and the Europeanization of certain subjects (it is not so much a matter of teaching new subjects or contents, but rather of teaching them differently). The programs are no longer as prescriptive as before, but rather insist more on the objectives and less on the content (a section that is more and more subject to the design given to it by the teachers), which favours a greater guarantee of success both for the teacher and for the student. Regarding the third category-specialized competence-it especially concerns the methodological resources and knowledge that each subject matter requires for it to be taught at school.

Ongoing training should have some general characteristics or orientations, such as the link between initial and continuing training (in the sense that the latter continues with matters of content from where the former left off); it should focus on the teachers' daily work (that is, on the school framework), plan a varied range of activities, and interpret continuing life-long training (permanent and continuing training).

\section{Final Assessment}

The analyses of the curricular organisation of the official Spanish system do not enable us to rigorously affirm the existence of a European focus in the school curriculum, given that in the evaluation criteria some objectives, contents and references refer to Europe or European issues, especially in some areas of humanities, but these are merely symbolic and inevitable. The school curriculum of the study plans has Spain and its internal cultures as the main geographical reference, but not Europe or the European 
Union. To a large extent the curriculum expresses what the teachers have been teaching in their classrooms, and the result of their updating or their recycling in European perspectives is hardly noticeable.

However, the European dimension of education has a greater presence in other educational actions such as research, extra-curricular activities, the learning of languages, mobility of students, teachers and administrators. In the school as well, as we have been able to see, a large number of actions and practices with a European focus are carried out as a result of the European sensitivity and awareness of some teachers who show the pedagogical autonomy that the systems allow the academic action of the teacher as regards development of the curriculum, given that what the educational authorities demand and set are the objectives and competence. Throughout the academic year 2000-200I, different kinds of practice (workshops, dossiers, talks, campaigns, markets, etc.) concerning European currency have been carried out in most schools, on the initiative of the schools themselves, the teachers, and parents' associations, given that the euro will come into circulation in January 2002.

In short, it seems that we can conclude that, from the perspective of the political and administrative design of the school curriculum to be developed in the educational institutions (primary, secondary and teacher training), there is no clear European focus that structures and orients academic action taking the European Union as a reference.

Nevertheless, during the last decade of the twentieth century, considerable reference to Europe in curricular practice as well as in pedagogical research and the cultural dimension of the school (outings, trips, extra-curricular activities, etc.) can be seen. This indicates, on the one hand, the autonomous leeway of schools and teachers in the curricular design and, on the other hand, the European awareness present in the professional groups that participate in education. This effort should also be interpreted as a call to the European institutions with a view to facilitating a greater array of resources and means that support, recompense and stimulate European action in the school through programs and other specific normative actions.

Finally, we wish to emphasize that curricular action with a European focus should also be interpreted from the aspect of the service it offers to society in the cultural construction of European citizenship, a challenge that was established in the Treaty of the Union passed in Maastricht in 1992 and which has in the school one of the most defined and useful vehicles for making it effective. The school must be the great element in the building of European citizenship, in order to construct a citizen characterised by solidarity and responsibility (Morin, 2000).

\section{Notes}

I Ministerial orders, decrees, and laws are published in the Spanish Official State Bulletin (Boletin Oficial del Estado). 


\section{References}

Aguilar Hernández, L. (1999). La Unión Europea y la educación, Cuadernos de Pedagogía, 279, $82-86$.

Cano, G. (Ed.). (2000). Informe educativo 200o. Evaluación de la LOGSE. Madrid: Santillana.

Comisión Europea. (1997). La escolarización de niños gitanos e itinerantes. Luxemburgo, Oficina de Publicaciones Oficiales de las Comunidades Europeas.

Commission Européenne. (1995). Les chiffres clés de l'éducation dans l'Union Européenne 94. Luxembourg: Office des Publications Officielles des Communautés Européennes.

Commission of the European Communities. (1993). Green paper on the European dimension of education. COM 93/457 final (29-9-1993).

Conclusions of the council and the ministers of education meeting within the council of I June 1992 on the development of open and distance learning in the European Community. Official Journal of the European Communities, C ISI (16-6-1992).

Consejo de Europa. (1999a). La dimensión europea de la educación secundaria. Madrid: Anaya/ MEC.

Consejo de Europa. (1999b). ¿Qué educación secundaria para una Europa en transformación? Tendencias, retos y perspectivas. Madrid: Anaya/MEC.

Council decision 95/819/EC of I4 March 1995 establishing the community action programme

"Socrates." Official Journal of the European Communities, L 87 (20-04-1995).

Decision 253/2000/EC, of 24 January 2000, of the European parliament and of the council establishing the second phase of the community action programme in the field of education

"Socrates." Official Journal of the European Communities, L 28 (03-02-2000).

Etxeberría, F. (2000). Políticas educativas en la Unión Europea. Barcelona: Ariel.

Ley 14/1970, de 4 de agosto, General de Educación y Financiamiento de la Reforma Educativa. Boletin Oficial del Estado, I87 (6-8-1970).

Ley Orgánica II/1983, de 25 de agosto, de Reforma Universitaria. Boletín Oficial del Estado, 209 (I-9-I983).

Ley Orgánica I/1990, de 3 de octubre, de Ordenación General del Sistema Educativo. Boletín Oficial del Estado, 238 (4-IO-I990).

Morin, E. (1998). Pensar Europa. Barcelona: Gedisa.

Morin, E. (200o). La mente bien ordenada. Barcelona: Seix Barral.

Orden Ministerial, de 30 de octubre de 1992, sobre regulación de intercambios escolares. Boletin Oficial del Estado, 268 (7-II-1992).

Orden Ministerial, de 28 de febrero de I994, sobre el procedimiento para la provisión de vacantes de personal funcionario docente en el extranjero. Boletín Oficial del Estado, 54 (8-31994).

Real Decreto I006/I99I, de I4 de junio, por el que se establecen las enseñanzas mínimas de educación primaria. Boletín Oficial del Estado, I52 (26-6-I99I).

Real Decreto I344/I99I, de 6 de septiembre, por el que se establece el currículo de educación primaria. Boletin Oficial del Estado, 220 (I3-9-199I).

Real Decreto 1345/1991, de 6 de septiembre, por el que se establece el currículo de educación secundaria obligatoria. Boletín Oficial del Estado, 220 (13-9-199I).

Real Decreto II78/1992, de 2 de octubre, por el que se establece el currículo del bachillerato. Boletin Oficial del Estado, 243 (2I-IO-I992).

Real Decreto 806/1993, de 28 de mayo, sobre régimen de centros docentes extranjeros en España. Boletín Oficial del Estado, I49 (23-6-1993).

Real Decreto 1027/1993, de 25 de junio, por el que se regula la acción educativa en el exterior. Boletin Oficial del Estado, I87 (6-8-1994).

Real Decreto 1396/1995, de 4 de agosto, por el que se regula un segundo sistema general de reconocimiento de formaciones profesionales en los Estados miembros de la Unión Europea y de los demás estados signatarios del acuerdo sobre espacio económico europeo. Boletín Oficial del Estado, 200 (22-8-1995). 
Real Decreto 2073/1995, de 22 de diciembre, por el que se modifica la normativa que regula el reconocimiento de títulos de enseñanza superior de nacionales de estados miembros de la Comunidad Europea que exigen una formación mínima de tres años. Boletin Oficial del Estado, 29 (2-2-1996).

Real Decreto 1754/I998, de 3I de julio, que incorpora al derecho español las Directivas Comunitarias y modifica los anexos de los Reales Decretos relativos al sistema general de reconocimientos de títulos y formaciones profesionales de los Estados miembros de la Unión Europea y demás Estados signatarios del Acuerdo sobre el Espacio Económico Europeo. Boletin Oficial del Estado, 253 (22-10-1998).

Real Decreto 3473/2000, de 29 de diciembre, por el que se modifica el Real Decreto I007/I99I por el que se establecen las enseñanzas mínimas correspondientes a la educación secundaria obligatoria. Boletín Oficial del Estado, I4 (I6-I-200I).

Real Decreto 3474/2000, de 29 de diciembre, por el que se modifican el Real Decreto 1700/199I por el que se establece la estructura del bachillerato, y el Real Decreto II78/1992 por el que se establecen las enseñanzas mínimas del bachillerato. Boletín Oficial del Estado, I4 (I6-I-200I).

Recommendation IIIO on distance teaching (1989). Parliamentary assembly of the Council of Europe. Retrieved from stars.coe.int/ta/ta89/erec1110.htm

Resolution of the council and of the ministers of education, meeting within the council, of 9 February 1976 comprising an action programme in the field of education. Official Journal of the European Communities, $C_{38}$ (19-2-1976).

Resolution of the ministers of education, meeting within the council, of 6 June 1974 on cooperation in the field of education. Official Journal of the European Communities, C 98 (20-8-1974).

Resolution on the information society: a challenge for education policies? (1989). Sixteenth session of the standing conference of ministers of education of the Council of Europe (Istanbul, II/I2-IO-I989). Retrieved from culture.coe.int/Infocentre/txt/eng/ eres89istanbulı.htm 